\title{
Peranan Penatalayanan Administrasi Bagi Efektivitas Pelayanan Gembala Jemaat
}

\author{
Matius Julianes \\ Sekolah Tinggi Teologi Tenggarong \\ Email: matius.alpian@gmail.com \\ Barthomius K. Jiu \\ Sekolah Tinggi Teologi Tenggarong \\ Email: barthomius@stttenggarong.ac.id \\ Mikha Agus Widiyanto \\ Sekolah Tinggi Teologi Tenggarong \\ Email: mikha.agus08@gmail.com
}

\begin{abstract}
:
Administration stewardship needs to be organized and managed properly. The availability of administrative data is very helpful for pastors in planning and designing pastoral care services, so as to support the realization of effective pastoral care services. This research aimed to examine the role of administrative stewardship for the effectiveness of the ministry of pastors. This research used a correlational method. The results showed that there was a positive and significant role of administrative stewardship for the ministry of the pastor effectiveness. Good stewardship administration with the availability of data that can be accessed easily and quickly, making pastoral care effective
\end{abstract}

Keywords: Stewardship, Administration, Ministry Effectiveness

\begin{abstract}
Abstrak:
Penatalayanan adminsitrasi perlu untuk ditata dan dikelola dengan baik. Ketersediaan data administrasi sangat membantu gembala dalam merencanakan dan mendisain pelayanan penggembalaan, sehingga menunjang terwujudnya pelayanan gembala jemaat yang efektif. Penelitian ini bertujuan untuk mengkaji peranan penatalayanan administrasi bagi efektivitas pelayanan gembala jemaat. Penelitian ini menggunakan metode korelasional. Hasil penelitian menunjukkan bahwa terdapat peranan yang positif dan signifikan penatalayanan administrasi bagi efektivitas pelayanan gembala jemaat. Penatalayanan administrasi yang baik dengan ketersediaanya data yang dapat diaskses dengan mudah dan cepat, membuat pelayanan gembala menjadi efektif.
\end{abstract}

Kata Kunci: Penatalayanan, Administrasi, Efektivitas Pelayanan

\section{Pendahuluan}

Gereja sebagai lembaga yang memiliki keanggotaan baik jemaat maupun majelis, maka dalam pengelolaannya diperlukan penatalayanan administrasi (Bagindo, 2016). Melalui penatalayanan inilah data jemaat dapat dikelola dan menjadi sumber informasi yang bermanfaat dalam memberikan layanan guna kebutuhan-kebutuhan administrasi. Melalui penyimpanan data jemaat yang baik maka dapat dimanfaatkan dalam pemberian tugas pelayanan, pelaksanaan pelayanan pastoral, penjadwalan pelayanan kunjungan dan pelayanan lainnya. Pelayanan administrasi gereja sebagian besar di Gereja Kemah Injil Indonesia di Daerah Mahakam Utara 
Kabupaten Kutai Kartanegara masih dilakukan secara konvensional. Pelaksanaan tugas pelayanan ini masih tersentral pada gembala jemaat sebagai pemimpin gereja.

Di era disruptif semestinya penatalayanan administrasi gereja sudah berbasis web. Penggunaan web tentunya akan memudahkan dalam pencarian data dan membuat pelayanan admnistrasi akan lebih cepat (Manulangga \& Gultom, 2016). Tentunya melalui penerapanan ini akan sangat membantu gembala jemaat dalam mengoptimlakan pelayanan penggembalaan. Ketersediaan penatalayanan administrasi yang baik akan sangat membantu gembala jemaat dalam mengolah sumber data untuk merencanakan, mendisain, melaksanakan dan mengevaluasi pelayanan yang dilaksanakannya (Susabda, 2016). Dalam hal inilah peran gembala sebagai pemimpin gereja sangat fundamental dalam seluruh kehidupan pelayanan gereja (Kosta \& Djadi, 2011).

Keberhasilan dalam pelayanan penggembalaan tidak dapat dipisahkan dari peran penatalayanan gereja. Gembala jemaat dalam melaksanakan tugasnya memerlukan penatalayanan gereja yang baik. Pelayanan-pelayanan yang dipercayakan perlu untuk ditata dan kelola dengan baik, secara khusus dari aspek administrasinya. Melalui penatalayanan inilah gembala dapat melaksanakan tugas pelayanannya secara efektif. Orientasi pada pelaksanaan tugas pelayanan pada kualitas, sehingga hasil pelayanan dapat memuaskan para stakeholders (jemaat dan majelis gereja).

Penatalayanan administrasi atau yang dikenal dengan administrasi gereja sebagai proses penyelenggaraan secara teratur kegiatan gereja melalui tahap perencanaan, pelaksanaan, dan pengawasan untuk mencapai tujuan pelayanan gereja. Penatalayanan terkait dengan pekerjaan menata dan melayani. Artinya pelaksana tugas itu bertanggungjawab untuk mengelolanya dengan baik sebagai bentuk kesediaan dirinya melayani. Orang yang melaksanakan tugas ini dinamakan juru kunci (Anwari, 1984). Kejadian 24 menceritakan tentang Abtraham yang memberikan kepercayaan kepada Eliezer untuk mengelola dan menangani rumah tangga dan segala harta miliknya. Eliezer sebagai juru kunci dalam mengelola harta yang dimiliki Abraham. Dalam tugas ini Eliezer bertanggungjawab kepada Abraham dan mengikuti kehendak pemilik harta tersebut.

Istilah penatalayanan dalam Perjanjian Lama dikenal istilah Kepala Rumah Tangga (Kejadian 43:16) dalam bahsa Ibraninya ha-ish asher al. Sedangkan dalam Kejadian 44:4 menggunakan istilah asher al bayith yang artinya "orang yang kepadanya dipercayakan tanggungjawab dan tugas untuk mengepalai serta mengurus harta dan segala kegiatan dalam rumah tangga". Sedangkan istilah lainnya dalam Kejadian 15:3-4 dalam bahasa Ibrani "ben mesheg" artinya hamba yang lahir dalam rumah tuannya yang diterima dan memperoleh hak sebagai pewaris (Anwari, 1984; Tomatala, 1993).

Perjanjian Baru menggunakan istilah penatalayanan, yaitu oikonomos dari kata dalam Bahasa Yunani, yang bersal dari kata dasar oikos, yang memiliki arti sebagai rumah dan kata nemo yang berarti mengurus (Lukas 16:4; 12:42; 1 Korintus 4:1,2; Titus 1:7; 1 Petrus 4:10). Dalam 1 Korintus 4:1,2, Paulus menyebut dirinya dan teman-teman sekerjanya sebagai 
penatalayanan rahasia Allah. Dalam Titus 1:7, Paulus menyebut Penilik jemaat sebagai penatalayanan Allah. Sedangkan dalam 1 Petrus 4:10, Petrus menganggap dirinya dan orangorang percaya sebagai penatalayanan kasih karunia (Anwari, 1984; Tomatala, 1993).

Banyak gereja secara organsiasi memiliki jemaat yang banyak dan dikategorikan sebagai gereja besar, namun lemah dalam sistem penatalayanan administrasi. Akibatnya pelayanan di gereja itu tidak tertata, pelayanan gembala tidak efektif, sehingga fungsi gereja tidak dapat berjalan dengan maksimal. Misalnya gembala tidak mengenal anggota jemaatnya sendiri karena tidak adanya data anggota, penginjilan tidak berjalan dengan baik karena tidak terencana sehingga visi dan misi gereja sulit untuk dicapai, bahkan ada jemaat yang sakit tidak ada yang mengunjungi atau kunjungan pastoral sendiri menjadi terabaikan. Menurut Widiyanto dan Susanto (Widiyanto \& Susanto, 2020) gereja memiliki tanggungjawab untuk melakukan kunjungan pastoral yang tidak bisa dilalaikan. Dalam tugas inilah diperlukan data administrasi yang harus ditata dengan baik, sehingga memudahkan dalam pengelolaan informasi untuk memberikan pelayanan kepada jemaat. Melalui ketersediaan data administrasi jemaat, gembala dapat mengetahui alamat dan kontak yang dapat dihubungi, sehingga pelayanan pastoral dapat dilaksanakan dengan baik.

Usat (Usat, 2019) menyatakan bahwa seiring dengan perkembangan zaman dan dengan semakin kompleksnya tuntutan kebutuhan pelayanan dalam gereja yang disadari atau tidak, pasti ada pengaruh trend zaman yang menuntut semuanya serba cepat, canggih, efektif dan efisien. Oleh karena itu, gereja sebagai suatu organisasi memang memerlukan kemampuan manajerial dari pihak pengelola (manajemen). Tanpa mengabaikan unsur kuasa Allah dalam memberi pertumbuhan bagi gereja-Nya, sesungguhnya administrasi gereja itu sendiri adalah sebagai bagian yang utuh dan tak terpisahkan, dimana Allah memperlengkapi gereja dan para gembala jemaat untuk melakukan tugas pelayanannya dengan baik.

Gereja dalam pelayanannya kepada jemaat memerlukan pengelolaan administrasi yang baik. Gembala jemaat tidak akan pernah dapat mengingat setiap data jemaat dengan mengandalkan daya kemampuan ingatnya. Pertumbuhan jemaat dan perpindahan lokasi tempat tinggal yang tidak memungkinkan gembala jemaat mampu menghafal satu persatu. Penambahan jumlah jemaat dan semakin besar jumlah jemaat gereja, maka semakin kompleks data dan permasalahan yang muncul. Melalui penatalayanan administrasi semuanya dapat dikelola dan difungsikan, sehingga kompleksitas kebutuhan pelayanan dapat diminimalisasi dan diatasi dengan baik. Untuk itulah melalui penatalayanan administrasi sangat membantu ketika dapat dimanfaatkan dengan baik untuk kesejahteraan orang-orang yang menerima layanan. (Marliani, 2018).

Di era disurtif teknologi yang semakin berkembang, menuntuk gereja tetap mampu memberikan jawaban atas kebutuhan dan tuntutan dalam pelayanannya. Selain tuntutan akan pelayanan yang berkualitas, dituntut pula efisiensi dan efektifitas dari pelayanan yang dilakukan (Marliani, 2018). Sedangkan Monoarfa (2012) mengungkapkan bahwa efektivitas berkenaan dengan ukuran berhasil tidaknya pencapaian tujuan (Jones, 2013; Robbins \& 
Coulter, 2020). Dalam konteks pelayanan gereja, apabila dalam pelaksanaan tugas gembala jemaat berhasil mencapai tujuannya, maka pelayanan yang dilakukan berjalan dengan efektif. Gereja merupakan suatu organisasi yang perlu diatur sedemikian rupa, sehingga menunjang keberhasilan dalam mewujudkan efektivitas pelayanan gembala jemaat.

Moenir (Moenir, 2010) menyatakan bahwa pelayanan merupakan kegiatan membantu seseorang atau sekelompok orang dalam upaya usaha memenuhi kepentingan sesuai dengan haknya. Dalam organisasi pelayanan yang diberikan dilakukan secara tersistim, prosedural, metodis yang tetap memperhatikan efisiensi dan efektivitasnya. Pelayanan yang dilakukan gembala bukan untuk kepentingan pribadi, melainkan kepentingan gereja dimana dirinya melakukannya sebagai bentuk pengabdian kepada Tuhan. Konsep pelayanan demikian yang menjadi orientasi gembala jemaat untuk bertanggungjawab dengan mewujudkan pelayanan gereja yang efektif bagi jemaat. Dalam pelaksanaan tugas pelayanan tersebut dirinya akan berupaya pada pencapaian tujuan organisasi (Ferris dkk., 2010). Tugas gembala jemaat sebagai pemimpin gereja tidak hanya pada aspek pelayanan mimbar dan penggembalaan saja, melainkan dalam aspek-aspek lainnya secara menyeluruh (Tapel, 2000). Tanggungjawab tersebut salah satu diantaranya melakukan penatalayanan administrasi guna memenuhi kebutuhan dalam melayani jemaat.

Rumusan masalah dalam penelitian ini sebagai berikut: Apakah penatalayanan administrasi berperan bagi efektivitas pelayanan gembala jemaat? Tujuan dalam penelitian ini adalah untuk mengkaji seberapa efektif peran penatalayanan administrasi bagi pelayanan gembala jemaat.

\section{Metode}

Penelitian ini menggunakan metode korelasional dalam upaya memberikan jawaban akan permasalahan dalam mengkaji peranan penatalayanan administrasi bagi efektivitas pelayanan gembala jemaat. Penelitian ini dilakukan di Gereja Kemah Injil Indonesia Jemaat Jahab, Kabupaten Kutai Kartanegara. Jumlah sampel penelitian sebanyak 38 orang jemaat. Dalam memilih sampel penelitian dari populasi dengan menggunakan disain simple random sampling, yaitu pemilihan sampel dengan cara acak sederhana (Widiyanto, 2013).

Dalam pengumpulan data penelitian menggunakan kuesioner. Adapun kuesioner yang digunakan berbentuk tertutup, dimana telah disediakan sejumlah pilihan jawaban dan responden atau sampel penelitian hanya memilih salah satu alternatif jawaban yang disediakan. Kuesioner sebagai instrumen penelitian, disusun dengan menggunakan skala pengukuran model Likert. Instrumen penatalayanan administrasi ini diukur dengan indikator yang meliputi: 1) Penyusunan perencanaan \& program gereja yang tepat sasaran, 2) Data jemaat dapat terorganisir dengan baik, 3) Menjadi dasar bagi pengembangan pelayanan, 4) Mengantisipasi perubahan \& perkembangan kebutuhan pelayanan, dan 5) Sebagai bahan evaluasi atau penilaian kinerja pelayanan. Sedangkan instrumen efektivitas pelayanan gembala jemaat diukur dengan indikator yang meliputi: 1) Pencapaian tujuan pelayanan, 2) Pelayanan yang 
berkualitas, 3) Produktifitas dalam pelayanan, 4) Mampu beradaptasi dalam pelayanan, 5) Pengembangan dan evaluasi dalam pelayanan.

Pengujian instrumen dilakukan dengan uji validitas dan reliabilitas. Instrumen penatalayanan gereja terdiri dari 15 butir valid dengan koefisien reliabilitas sebesar 0,943. Sedangkan instrument efektivitas pelayanan gembala jemaat terdiri dari 15 butir valid dengan koefisien reliabilitasnya 0,933 . Teknik statistika yang digunakan dalam analisis data penelitian ini meliputi analisis statistika deskriptif dan inferensial. Statistika deskriptif meliputi perhitungan skor minimun dan maksimum, rata-rata, dan simpangan baku. Sedangkan statistika inferensial dengan menggunakan analisis korelasi sederhana dan regresi sederhana (Widiyanto, 2014).

\section{Hasil dan Pembahasan}

Berdasarkan analisis data statistika, diperoleh hasil sebagai berikut:

Tabel 1. Analisis Data Deskriptif Latar Belakang Responden

\begin{tabular}{|l|c|c|c|c|c|c|}
\hline & \multicolumn{2}{|c|}{ Jensi Kelamin } & \multicolumn{4}{c|}{ Pendidikkan } \\
\hline & Laki-Laki & Perempuan & SD & SMP & SMA & Sarjana \\
\hline Frekuensi & 21 & 17 & 1 & 6 & 18 & 13 \\
\hline Persen & 55,3 & 44,7 & 2,6 & 15,8 & 47,4 & 34,2 \\
\hline
\end{tabular}

Sumber: Hasil olah data penelitian

Berdasarkan hasil analisis data pada tabel di atas, memberikan informasi bahwa berdasarkan latar belakang jenis kelamin menunjukkan bahwa responden yang berjenis kelamin laki-laki sebanyak 21 orang atau 55,3\% yang lebih banyak dari responden berjenis kelamin perempuan dengan jumlah sebanyak 17 orang atau 44,7\%. Sedangkan berdasarkan latar belakang pendidikan bahwa responden yang berpendidikan SMA sebanyak 18 orang atau $47,4 \%$ yang lebih banyak dibandingkan yang berlatar belakang pendidikan SD sebanyak 1 orang atau 2,6\%, SMP sebanyak 6 orang atau 15,8\% dan sarjana sebanyak 13 orang atau 34,2\%.

Hasil analisis untuk data penatalayanan adminsitrasi dan efektivitas pelayanan gembala jemaat diperoleh sebagai berikut:

Tabel 2. Analisis Deskripsi Data Penelitian

\begin{tabular}{|l|c|c|c|c|c|}
\hline \multicolumn{1}{|c|}{ Variabel } & $\mathrm{N}$ & Minimum & Maximum & Mean & Std. Deviation \\
\hline $\begin{array}{l}\text { Penatalayanan } \\
\text { Administrasi }\end{array}$ & 38 & 39 & 60 & 49,89 & 5,511 \\
\hline $\begin{array}{l}\text { Efektivitas Pelayanan } \\
\text { Gembala Jemaat }\end{array}$ & 38 & 41 & 60 & 49,74 & 5,971 \\
\hline
\end{tabular}

Sumber: Hasil olah data penelitian 
Berdasarkan hasil analisis data pada tabel 2, menunjukkan bahwa nilai rata-rata dari penatalayanan administrasi sebesar 49,89 dengan simpangan baku sebesar 5,511. Terdapat sebanyak 19 orang atau 50,00\% yang menilai pelayanan administrasi gereja belum sepenuhnya baik yang ditandai dengan perolehan skor di bawah rata-rata, dan sebaliknya terdapat sebanyak 19 orang atau $50 \%$ yang memberikan penilaian terhadap pelayanan administrasi sudah baik yang ditandai perolehan skor di atas rata-rata. Sedangkan skor hasil pengukuran efektivitas pelayanan gembala jemaat diperoleh skor rata-rata sebesar 49,74 dengan simpangan baku sebesar 5,971. Terdapat sebanyak 19 orang atau 50,00\% yang menyatakan bahwa pelayanan yang dilaksanakan gembala jemaat telah efektif yang ditandai dengan perolehan skor di atas rata-rata. Terdapat sebanyak 19 orang atau 50,00\% yang menyatakan bahwa pelayanan yang dilaksanakan gembala jemaat belum efektif sepenuhnya yang ditandai dengan perolehan skor di bawah rata-rata.

Hasil pengujian distribusi normal memberikan informasi bahwa data untuk penatalayanan administrasi berada dalam sebaran normal yang ditandai dengan perolehan hasil statistika dengan menggunakan kolmogorof-smirnof sebesar 0,095 dengan koefisien $P$-value sebesar 0,882 yang tidak signifikan pada taraf signifikan $\alpha=0,05$. Sedangkan distribusi data efektivitas pelayanan gembala jemaat dipeoleh koefisien sebesar 0,155 dengan koefisien $P$ value sebesar 0,318 yang tidak signifikan pada taraf signifikan $\alpha=0,05$. Dengan demikian data penatalayanan gereja dan efektivitas pelayanan gembala jemaat berada dalam sebaran normal. Hasil analisis linearitas regresi dipeoleh persamaan regresi $\ddot{Y}=20,075+0,594 X$ dengan koefisien $\mathrm{F}$ hasil hitung sebesar 0,663 dengan nilai $P$-value sebesar 0,796 yang tidak signifikan pada taraf signifikan $\alpha=0,05$. Dengan demikian disimpulkan bahwa persamaan regresi efektivitas pelayanan gembala jemaat berbentuk linear.

Untuk mengetahui peran penatalayanan administrasi terhadap efektivitas pelayanan gembala dilakukan uji analisis menggunakan analisis korelasi dan regresi sebagai berikut:

Tabel 3. Hasil Uji Signifikansi Persamaan Regresi

\begin{tabular}{|l|l|r|r|r|r|r|}
\multicolumn{2}{|c|}{ ANOVA $^{\mathrm{a}}$} \\
\hline \multirow{3}{*}{1} & $\begin{array}{c}\text { Sum of } \\
\text { Squares }\end{array}$ & \multicolumn{1}{c|}{$\mathrm{df}$} & $\begin{array}{c}\text { Mean } \\
\text { Square }\end{array}$ & F & Sig. \\
\hline \multirow{3}{*}{1} & Regression & 397,083 & 1 & 397,083 & 15,500 &, $000^{\mathrm{b}}$ \\
\cline { 2 - 8 } & Residual & 922,286 & 36 & 25,619 & & \\
\cline { 2 - 8 } & Total & 1319,368 & 37 & & & \\
\hline
\end{tabular}

a. Dependent Variable: Efektivitas Pelayanan Gembala Jemaat

b. Predictors: (Constant), Penatalayanan Administrasi

Coefficients $^{\mathrm{a}}$

\begin{tabular}{|l|c|c|c|c|}
\hline Model & $\begin{array}{c}\text { Unstandardized } \\
\text { Coefficients }\end{array}$ & $\begin{array}{c}\text { Standardized } \\
\text { Coefficients }\end{array}$ & $\mathrm{t}$ & Sig. \\
\hline
\end{tabular}

M. Julianes, B. K. Jiu \& M. A. Widiyanto, Peranan Penatalayanan Administrasi ...... 


\begin{tabular}{|r|l|r|r|r|r|r|}
\hline \multicolumn{2}{|l|}{} & \multicolumn{1}{c|}{ B } & Std. Error & Beta & & \\
\hline \multirow{3}{*}{1} & (Constant) & 20,075 & 7,579 & & 2,649 &, 012 \\
\cline { 2 - 7 } & $\begin{array}{l}\text { Penatalayanan } \\
\text { Administrasi }\end{array}$ &, 594 &, 151 &, 549 & 3,937 &, 000 \\
\hline
\end{tabular}

a. Dependent Variable: Efektivitas Pelayanan Gembala Jemaat

Sumber: Hasil olah data penelitian

Dari hasil analisis pada tabel 3, diperoleh persamaan regresi $\ddot{Y}=20,075+0,594 \mathrm{X}$. Sedangkan hasil pengujian signifikansi persamaan regresi diperoleh koefisien $\mathrm{F}$ hasil hitung sebesar 15,500 dengan $P$-value sebesar 0,000 yang tidak signifikan pada taraf signifikan $\alpha=$ 0,05 . Hasil ini memiliki arti bahwa persamaan regresi $\ddot{Y}=20,075+0,594 \mathrm{X}$ adalah berarti memiki makna yang berarti dalam memberikan prediksi kontribusi penatalayanan administrasi gereja dalam mewujudkan pelayanan gembala yang efektif. Hasil ini mengandung makna bahwa apabila dilakukan perbaikan pada penatalayanan administrasi gereja melalui satu program, maka akan meningkatkan efektivitas pelayanan gembala jemaat sebesar 0,594 pada konstanta 20,075.

Tabel 4. Hasil Pengujian Peranan Penatalayanan Administrasi Bagi Efektivitas Pelayanan Gembala Model Summary

\begin{tabular}{|l|r|r|r|r|}
\hline Model & \multicolumn{1}{|c|}{ R } & R Square & $\begin{array}{c}\text { Adjusted R } \\
\text { Square }\end{array}$ & $\begin{array}{l}\text { Std. Error of } \\
\text { the Estimate }\end{array}$ \\
\hline 1 &, $549^{\mathrm{a}}$ &, 301 &, 282 & 5,062 \\
\hline
\end{tabular}

a. Predictors: (Constant), Penatalayanan Administrasi

Berdasarkan hasil analisis korelasi pada tabel di atas besarnya koefisien korelasi sebesar 0,549 menunjukkan bahwa peranan penatalayanan administrasi bagi efektivitas pelayanan gembala jemaat sedang atau cukup (Widiyanto, 2014). Dari hasil uji t didapatkan koefisien sebesar 3,937 dengan $P$-value sebesar 0,000 yang yang tidak signifikan pada taraf signifikan $\alpha$ $=0,05$. Dengan demikian dapat disimpulkan bahwa terdapat peranan yang positif dan signifikan penatalayanan administrasi bagi efektivitas pelayanan gembala jemaat. Hasil ini berarti bahwa semakin baik dalam pelaksanaan penatalayanan adminsitrasi, maka akan meningkatkan pelayanan gembala jemaat menjadi semakin efektif. Sedangkan besarnya koefisien determinasi $\left(\mathrm{r}^{2}\right.$ yx $)$ sebesar 0,282 mempunyai makna bahwa penatalayanan administrasi berperan dalam meningkatkan efektivitas pelayanan gembala jemaat sebesar $28,2 \%$, sedangkan sisanya sebesar $71,8 \%$ dipengaruhi oleh faktor faktor lainnya yang tidak dikaji dalam penelitian ini.

Pelayanan administrasi yang baik sebagai gambaran akan kualitas pelayanan dalam mewujudkan pelayanan yang efektif (Mansyur, 2013). Standar pelayanan administrasi yang baik akan mendatangkan kepuasan bagi penggunanya. Terkait dengan pelayanan gereja, 
dibutuhkan penatalayanan administrasi yang mudah untuk diakses dan penggunaannya. Ketersediaan penatalayanan ini akan menjadikan gembala dengan mudah merencanakan program pelayanan dan melaksanakannya. Ketersediaan data yang tepat bagi gembala bisa dimanfaatkan untuk memberikan pelayanan doa, pelayanan kunjungan pastoral dan juga pelayanan-pelayanan khusus yang dibutuhkan jemaat.

Gembala jemaat sebagai pemimpin gereja memiliki tugas-tugas tertentu (Sudjarwo, 2019), tugas sebagai pemimpin gereja salah satu diantaranya bertanggungjawab dalam penatalayanan administrasi dalam mewujudkan pelayanan gereja yang efektif. Gembala jemaat memiliki tanggungjawab untuk membawa gereja yang dipimpinnya mampu memberikan jawaban akan kebutuhan umat, salah satu diantaranya dengan menyediakan penatalayanan administrasi yang baik.

Sejalan dengan Usat (2019), sebagai organisasi melalui peran pemimpin, yaitu gembala jemaat sudah semestinya memberikan pelayanan dalam pengelolaannya yang cepat, canggih, efektif dan efisien. Pelayanan ini akan sangat membantu bagi gembala dalam mencari informasi guna pelaksanaan tugas pelayanannya. Orientasi pada pelayanan administrasi pada kepuasan yang menerima layanan. Ketersediaan data yang dapat diakses dengan mudah membuat gembala dapat memberikan layanan yang memuaskan jemaat, sehingga pelayanan tersebut menjadi efektif dan efisien. Dalam perspektif psikologis, pelayanan administrasi prima yang diberikan gereja dalam memenuhi kebutuhan dan keinginan jemaat, maka akan mendatangkan kepuasan dan yang akhirnya meningkatkan kepercayaan bagi penerima layanan (Hadjam, 2001).

\section{Kesimpulan}

Berdasarkan hasil analisis disimpulkan bahwa penatalayanan administrasi memiliki peran yang signifikan terhadap efektivitas pelayanan gembala jemaat. Dalam merencanakan, mendisain dan melaksanakan pelayanan, gembala jemaat memerlukan data administrasi yang dapat secara mudah dan cepat diakses. Ketersediaan data ini sangat membantu bagi gembala jemaat untuk melaksanakan tugas pelayanan penggembalaan dalam menuntun dan membina jemaat bertumbuh dalam kehidupan rohaninya.

Di era kemajuan teknologi dan informasi dibutuhkan ketersediaan data administrasi yang mudah diakses dengan penyediaan layanan yang berbasis pada digital. Untuk itu, hendaknya gereja mengembangkan administrasinya dengan layanan berbasis teknologi informasi yang up to date dengan perkembangan secara khusus di era disruptif teknologi informasi, seperti penerapannya berbasis web. Gembala jemaat melalui sinergisitas dengan majelis dapat mengembangkan penatalayanan administrasi gereja yang dapat dihandalkan guna menjawab kebutuhan pelayanan bagi jemaat secara cepat, efisien dan efektif. 


\section{Daftar Rujukan}

Anwari, M. S. (1984). Peranan Penatalayanan dalam Pengembangan Jemaat. Malang: Gandum Mas.

Bagindo, F. S. N. (2016). Analisis dan Perancangan Sistem Informasi Administrasi Gereja Pada Gereja HKBP Kamal Raya Ressort Cengkareng. Jurnal Informasi dan Bisnis. 5(1), 7585.

Ferris, D. L., Lian, H., Brown, D. J., Pang, F. X. J., \& Keeping, L. M. (2010). Self-esteem and job performance: The moderating role of self-esteem contingencies. Personnel Psychology, 63(3), 561-593. https://doi.org/10.1111/j.1744-6570.2010.01181.x

Hadjam, M. N. R. (2001). Efektivitas Pelayanan Prima Sebagai Upaya Meningkatkan Pelayanan Di Rumah Sakit (Perspektif Psikologi). Jurnal Psikologi, 2, 105-115.

Jones, G. R. (2013). Organizational theory, design, and change (7. ed., global ed). New Jersey: Pearson Education, Inc.

Kosta, Y., \& Djadi, J. (2011). Peranan Gembala Sebagai Pemimpin Dalam Perspektif I Petrus 5:1-4 Dan Relevansinya Pada Masa Kini. Jurnal Jaffray, 9(2), 172-200. https://doi.org/10.25278/jj71.v9i2.100

Mansyur, S. (2013). Efektivitas Pelayanan Publik dalam Perspektif Konsep Administrasi Publik. Jurnal Academika, 5(1), 965-972.

Manulangga, G., \& Gultom, S. (2016). Ssitem Informasi Penatalayanan Jemaat Gereja HKBP Kupang Berbasis WEB. Jurnal Ilmiah Flash, 2(2), 87. https://doi.org/10.32511/jiflash.v2i2.29

Marliani, L. (2018). Definisi Administrasi Dalam Berbagai Sudut Pandang. DINAMIKA: Jurnal Ilmu Administrasi Negara. 5(4), 17-21.

Moenir, A. S. (2010). Manajemen Pelayanan Umum di Indonesia. Bumi Aksara.

Monoarfa, H. (2012). Efektivitas dan Efisiensi Penyelenggaraan Pelayanan Publik: Suatu Tinjauan Kinerja Lembaga Pemerintahan. Jurnal Pelangi Ilmu, 05(01), 21-29.

Robbins, S. P., \& Coulter, M. K. (2020). Management (15 Edition). New Jersey: Pearson Education, Inc.

Sudjarwo, M. (2019). Mengaplikasikan Integritas Gembala Jemaat menurut Surat-surat Penggembalaan. Jurnal Teologi dan Pelayanan Kristiani EPIGRAPHE, 3(2), 173-189.

Susabda, Y. B. (2016). Prinsip-Prinsip Pertimbangan Utama dalam Administrasi Gereja. Malang: Gandum Mas.

Tapel, H. T. (2000). Kamus Teologi. Jakarta: BPK Gunung Mulia.

Tomatala, Y. (1993). Penatalayanan Gereja yang Efektif di Dunia Modern. Malang: Gandum Mas.

Usat, Y. (2019). Kepemimpinan Blusukan: Model Kepemimpinan Kristen Yang Membumi. INTEGRITAS: Jurnal Teologi, 1(2), 93-100.

Widiyanto, M. A. (2013). Statistika Terapan. Konsep dan Aplikasi dalam Penelitian Bidang Pendidikan, Psikologi dan Ilmu Sosial Lainnya. Jakarta: Elex Media Komputindo. 
Widiyanto, M. A. (2014). Statistika untuk Penelitian Bidang Teologi, Pendidikan Agama Kristen, dan Pelayanan Gereja. Bandung: Kalam Hidup.

Widiyanto, M. A., \& Susanto. (2020). Pengaruh Pelayanan Kunjungan Pastoral terhadap Pertumbuhan Rohani Jemaat. Evangelikal: Jurnal Teologi Injili dan Pembinaan Warga Jemaat, 4(1), 39-46. https://journal.sttsimpson.ac.id/index.php/EJTI/article/view/214 